\title{
META ANALISIS : FINANCIAL DISTRESS DI PERUSAHAAN
}

\author{
Michelia Putri Catherina Sujatna1, Yulia Hayatul², Syauqy Syauqy Abdul Muluk ${ }^{3}$ \\ 1,2,3IImu Administrasi Bisnis, Fakultas Ilmu Sosial dan Ilmu Politik, Universitas Padjadjaran \\ micheliaputri@yahoo.com¹,yulia.hayatul24@gmail.com², syauqyy@gmail.com³
}

\begin{abstract}
ABSTRAK
Tujuan Penelitian ini adalah (1). Bagaimana pengaruh Perputaran kas pada profitabilitas (2). Bagaimana pengaruh Perputaran persediaan terhadap profitabilitas (3). Bagaimana Pengaruh profitabilitas dan financial distress terhadap kinerja keuangan perusahaan. Hasil penelitian adalah Perputaran Kas yang terjadi di perusahaan Otomotif dan Komponennya periode Tahun 2010 2013 rata rata mempunyai perputaran kas sebanyak 16 kali putaran dan termasuk dalam kriteria cukup. (2) Perputaran Persediaan yang terjadi di perusahaan Otomotif dan Komponennya periode Tahun 2010 - 2013 rata rata mempunyai perputaran Persediaan sebanyak 6 kali putaran dan termasuk dalam kriteria cukup. (3) Profitabilitas yang terjadi di perusahaan Otomotif dan Komponennya periode Tahun 2010 - 2013 rata rata mempunyai Profitabilitas sebesar 10,12\% dan termasuk ke dalam kriteria cukup. (4) Hasil pengujian korelasi perputaran kas menunjukan perputaran kas sangat rendah dan mempunyai arah negatif, Sedangkan perputaran persediaan menunjukan korelasi yang rendah. Hasil pengujian perputaran kas dan perputaran persediaan terhadap profitabilitas menyatakan bahwa perputaran kas dan perputaran persediaan secara simultan tidak berpengaruh terhadap profitabilitas pada perusahaan otomotif dan komponennya yang terdaftar di Bursa Efek Indonesia (BEI) periode 2010-2013.
\end{abstract}

Kata Kunci : Laba, Perputaran Kas, financial distress, Bursa Efek Indonesia

\begin{abstract}
The objectives of this study are (1). How is the effect of cash turnover on profitability (2). How is the effect of inventory turnover on profitability (3). How is the effect of profitability and financial distress on the company's financial performance. The results of the study are cash turnover that occurred in automotive companies and their components in the period 2010 - 2013 on average had cash turnover of 16 times and was included in the sufficient criteria. (2) Inventory turnover that occurred in Automotive companies and their components for the period 2010 - 2013 had an average inventory turnover of 6 times and was included in the sufficient criteria. (3) Profitability that occurred in the automotive company and its components for the period 2010 - 2013 on average had a profitability of $10.12 \%$ and was included in the sufficient criteria. (4) The results of the cash turnover correlation test show that cash turnover is very low and has a negative direction, while inventory turnover shows a low correlation. The results of testing cash turnover and inventory turnover on profitability state that simultaneous cash turnover and inventory turnover have no effect on profitability in automotive companies and their components listed on the Indonesia Stock Exchange (IDX) 2010-2013.
\end{abstract}

Keywords: Profit, Cash Turnover, financial distress, Indonesia Stock Exchange 


\section{PENDAHULUAN}

Persaingan dunia ekonomi saat ini yang semakin ketat dan semakin kuat. Hal ini dapat berpengaruh dalam perkembangan perekonomian secara nasional maupun internasional. Adanya persaingan yang semakin ketat dan semakin kuat tersebut, menyebabkan biaya yang akan dikeluarkan oleh perusahaan akan semakin tinggi, hal ini akan mempengaruhi kinerja perusahaan. Apabila suatu perusahaan tidak mampu untuk bersaing maka perusahaan tersebut akan mengalami kerugian, yang pada akhirnya bisa membuat suatu perusahaan mengalami financial distress. Masalah keuangan yang dihadapi suatu perusahaan apabila dibiarkan berlarut-larut dapat mengakibatkan terjadinya kebangkrutan. Apabila kondisi financial distress ini diketahui sejak awal, diharapkan dapat dilakukan tindakan untuk memperbaiki situasi tersebut sehingga perusahaan tidak akan masuk ke tahap kesulitan yang lebih berat seperti kebangkrutan atau likuidasi.

Setiap perusahaan yang baik harus mencermati dan menganalisis perkembangan kegiatan usahanya dari waktu ke waktu agar dapat diketahui apakah perusahaan mengalami kemajuan atau kemunduran dan perlu mengetahui keadaan keuangan pada saat tertentu dengan menganalisis laporan keuangan. Oleh karena itu dalam rangka pengambilan keputusan, pengelola perusahaan memerlukan informasi khususnya informasi mengenai apa yang akan terjadi dimasa yang akan datang. Informasi yang cepat dan berkesinambungan berupa informasi akuntansi dalam bentuk laporan keuangan dapat membantu perusahaan untuk mengetahui keadaan dan kinerja ekonomi suatu perusahaan.

Laporan keuangan adalah laporan yang menunjukkan kondisi keuangan perusahaan pada saat ini atau dalam suatu periode tertentu
(Kasmir, 2008:7). Laporan keuangan yang dibuat oleh perusahaan biasanya terdiri atas neraca, laporan laba rugi, laporan perubahan modal, laporan arus kas dan catatan atas laporan keuangan. Menurut Skousen dkk (2011 : 284), laporan arus kas menjelaskan perubahan pada kas atau setara kas (cash equivalent) dalam periode tertentu. Setara kas adalah investasi jangka pendek yang amat likuid yang bisa segera ditukar dengan kas. Dalam laporan arus kas, penerimaan dan pengeluaran kas diklasifikasikan menurut tiga kategori utama yaitu : aktivitas operasi, aktivitas investasi, aktivitas pendanaan.

Laporan keuangan yang baik terdiri dari laporan posisi keuangan, laporan laba rugi, laporan ekuitas pemegang -saham, laporan arus kas, dan catatan atas laporan keuangan. Ketiga aktivitas laporan arus kas ini merupakan salah satu hal terpenting yang digunakan manajemen dalam menilai kinerja keuangan suatu perusahaan. Kinerja keuangan merupakan gambaran kondisi keuangan perusahaan pada suatu periode tertentu. Salah satu bagian dari laporan keuangan yang dapat digunakan untuk mengukur kinerja keuangan adalah laporan arus kas.

Tujuan yang paling mendasar dari operasi perusahaan adalah memperoleh laba yang optimal. Profitabilitas suatu perusahaan menunjukan perbandingan antara laba dengan aktiva atau modal yang menghasilkan laba tersebut (Riyanto, 2001). Kekurangan kas menyebabkan perusahaan tidak mampu membayar kewajiban dalam jangka pendek seadangkan kekurangan persediaan akan menyebabkan perusahaan tidak dapat memperoleh keuntungan karena calon pembeli tidak jadi membeli ke perusahaan tersebut (Ridwan, 2007). Arus kas juga merupakan laporan yang memberikan informasi yang relevan mengenai penerimaan dan pengeluaran kas dalam periode waktu tertentu. Setiap perusahaan dalam menjalankan operasi usahanya akan 
mengalami arus masuk kas (cash inflows) dan arus keluar kas (cash outflows). Apabila arus kas yang masuk lebih besar daripada arus kas yang keluar maka hal ini akan menunjukkan positive cash flows, sebaliknya apabila arus kas masuk lebih sedikit daripada arus kas keluar maka akan tejadi negative cash flows.

Informasi arus kas dibutuhkan pihak kreditor untuk mengetahui kemampuan perusahaan dalam pembayaran hutangnya. Apabila arus kas suatu perusahaan jumlahnya besar, maka pihak kreditor mendapatkan keyakinan pengembalian atas kredit yang diberikan. Jika arus kas suatu perusahaan bernilai kecil, maka kreditor tidak mendapatkan keyakinan atas kemampuan perusahaan dalam membayar hutang. Jika hal ini berlangsung secara terus menerus, kreditor tidak akan mempercayakan kreditnya kembali kepada perusahaan karena perusahaan dianggap mengalami permasalahan keuangan atau financial distress. Dengan kondisi demikian maka arus kas dapat dijadikan indikator oleh pihak kreditor untuk mengetahui kondisi keuangan perusahaan. Atas dasar ini peneliti ingin membuktikan secara empiris mengenai kemampuan informasi arus kas dalam memprediksi kondisi financial distress suatu perusahaan.

Berdasarkan latar belakang masalah tersebut, rumusan masalah dalam penelitian ini yaitu: (1) Apakah laba berpengaruh terhadap kondisi financial distress pada perusahaan sektor aneka industri dan sektor industri barang konsumsi yang terdaftar di Bursa Efek Indonesia? (2) Apakah arus kas berpengaruh terhadap kondisi financial distress pada perusahaan sektor aneka industri dan sektor industri barang konsumsi yang terdaftar di Bursa Efek Indonesia? (3) Apakah laba dan arus kas berpengaruh terhadap kondisi financial distress pada perusahaan sektor aneka industri dan sektor industri barang konsumsi yang terdaftar di Bursa Efek Indonesia?
Dengan demikian, tujuan yang ingin dicapai dalam penelitian ini adalah untuk; (1) mengetahui pengaruh laba terhadap kondisi financial distress pada perusahaan sektor aneka industri dan sektor industri barang konsumsi yang terdaftar di Bursa Efek Indonesia, (2) mengetahui pengaruh arus kas terhadap kondisi financial distress pada perusahaan sektor aneka industri dan sektor industri barang konsumsi yang terdaftar di Bursa Efek Indonesia, (3) mengetahui pengaruh laba dan arus kas terhadap kondisi financial distress pada perusahaan sektor aneka industri dan sektor industri barang konsumsi yang terdaftar di Bursa Efek Indonesia.

\section{TUJUAN PENELITIAN}

1. Bagaimana pengaruh Perputaran kas pada profitabilitas

2. Bagaimana pengaruh Perputaran persediaan terhadap profitabilitas

3. Bagaimana Pengaruh profitabilitas dan financial distress terhadap kinerja keuangan perusahaan

\section{METODOLOGI PENELITIAN}

Metode yang digunakan dalam penelitian ini adalah deskriptif dan metode verifikatif. Metode deskriptif adalah metode yang digunakan untuk mendeskripsikan atau memberi gambaran terhadap objek penelitian melalui data sampel atau populasi sebagaimana adanya, tanpa bermaksud membuat kesimpulan yang berlaku umum atau generaliasasi (Sugiyono, 2013). Sedangkan metode verifikatif digunakan untuk melakukan uji hipotesis melalui pengolahan dan pengujian secara sistematis yaitu menguji pengaruh kas, perputaran kas dan perputaran persediaan terhadap profitabilitas dan kinerja keuangan perusahaan serta menguji pengaruh 
hubungan profitabilitas dan financial distress terhadap kinerja keuangan perusahaan.

Teknik pengambilan sampel yang digunakan adalah purposive sampling, yaitu teknik penentuan sample dengan pertimbangan tertentu (Sugiyono, 2013). Sample yang digunakan dalam penelitian ini dipilih berdasarkan kriteria sebagai berikut: (1) Perusahaan yang terdaftar di Bursa Efek Indonesia (BEI) pada kurun waktu penelitian 2010-2013 dan tidak di delisting selama kurun waktu penelitian tersebut. (2) Perusahaan Otomotif dan Komponennya yang terdaftar di BEI yang menerbitkan laporan keuangan secara berturut-turut pada periode 20102013. (3) Perusahaan yang mengalami keuntungan (profit) selama periode pengamatan. (4) Perusahaan yang menerbitkan laporan keuangan dengan mata uang rupiah

\section{Teknik Analisis Data}

Alat analisis yang digunakan dalam penelitian ini adalah maksimal, minimal, rata-rata (mean) dan standar deviasi untuk mendeskripsikan variabel perputaran kas, perputaran persediaan dan profitabilitas (ROA) pada perusahaan otomotif dan komponennya yang terdaftar di Bursa Efek Indonesia (BEI) selama 2011-2013.

\section{Skor Rata-rata}

Rata-rata (mean) merupakan teknik penjelasan kelompok yang didasarkan atas nilai-nilai dari kelompok tersebut (Sugiyono, 2013). Rata-rata didapat dengan menjumlahkan seluruh data perusahaan dalam kelompok tertentu.

2. Standar Deviasi

Standar deviasi atau simpangan baku merupakan salah satu teknik statistic yang digunakan untuk menjelaskan homogenitas kelompok. Standar deviasi merupakan akar varians atau akar jumlah kuadrat semua deviasi nilai-nilai individual terhadap ratarata kelompok (Sugiyono, 2013).

\section{Analisis Korelasi}

Analisis kolerasi bertujuan untuk mengukur ada atau tidaknya hubungan serta arah hubungan dua variabel atau lebih. Dalam analisis korelasi terdapat koefisien korelasi. Koefisien korelasi yaitu angka yang menyatakan derajat hubungan antara variabel independen dengan variabel dependen atau untuk mengetahui kuat atau lemahnya hubungan antara variabel independen dengan variabel dependen. Variabel yang akan diuji korelasinya adalah perputaran kas, perputaran persediaan dan profitabilitas (ROA). Adapun kriteria penilaian korelasi menurut Sugiyono (2013:) yaitu:

\begin{tabular}{|l|l|}
\hline \multicolumn{2}{|c|}{ Tabel 2. Kriteria Korelasi } \\
\hline Interval koefisien & \multicolumn{1}{|c|}{ Tingkat Hubungan } \\
\hline $0,00-0,199$ & Sangat Rendah \\
\hline $0,20-0,399$ & Rendah \\
\hline $0,40-0,599$ & Sedang \\
\hline $0,60-0,799$ & Kuat \\
\hline $0,80-1,00$ & Sangat kuat \\
\hline
\end{tabular}

\section{PEMBAHASAN}

Perusahaan Otomotif dan Komponennya yang terdaftar di Bursa Efek Indonesia periode tahun 2010 - 2013. Berdasarkan kriteria yang ditetapkan maka diperoleh sebanyak 8 perusahaan sehingga jumlah data yang digunakan pada penelitian ini sebanyak 32 data. 
Tabel 3. Perputaran Kas Perusahaan Otomotif dan Komponennya

\begin{tabular}{|l|l|l|l|l|l|l|}
\hline \multirow{2}{*}{ Kode } & \multicolumn{5}{|c|}{ Terputaran Kas } \\
\cline { 2 - 6 } & $\mathbf{2 0 1 0}$ & $\mathbf{2 0 1 1}$ & $\mathbf{2 0 1 2}$ & $\mathbf{2 0 1 3}$ & $\begin{array}{c}\text { Rata - } \\
\text { rata } \\
\text { Perusahaa } \\
\text { n }\end{array}$ & Kriteria \\
\hline ASII & 16,52 & 16,16 & 15,56 & 13,09 & 15,34 & Cukup \\
\hline GJTL & 11,72 & 16,3 & 16,87 & 8,51 & 13,35 & Cukup \\
\hline IMAS & 23,67 & 15,14 & 14,42 & 17,81 & 17,76 & Cukup \\
\hline LPIN & 2,11 & 1,68 & 1,61 & 1,53 & 1,73 & Rendah \\
\hline PRAS & 26,3 & 19,97 & 39,48 & 31,68 & 29,36 & Tinggi \\
\hline SMSM & 13,37 & 11,09 & 5,29 & 3,03 & 8,2 & Rendah \\
\hline TURI & 27,57 & 27,09 & 28,97 & 46,74 & 32,59 & Tinggi \\
\hline UNTR & 18,15 & 12,99 & 10,05 & 8,55 & 12,44 & Rendah \\
\hline Rata - rata per & 17,43 & 15,05 & 16,53 & 16,37 & 16,35 & Cukup \\
\hline Tahun & 27,57 & 27,09 & 39,48 & 46,74 & 35,22 & Tinggi \\
\hline Max & 2,11 & 1,68 & 1,61 & 1,53 & 1,73 & Rendah \\
\hline Min & & & & & & \\
\hline
\end{tabular}

Sumber: data yang telah diteliti

Perputaran kas menggambarkan kecepatan arus kas kembali menjadi kas yang telah diinvestasikan. Tingkat perputaran kas menunjukan kecepatan perubahan kembali aktiva lancar menjadi kas. Rata-rata perputaran kas pada perusahaan otomotif dan komponennya pada tahun 2010 menunjukkan tingkat perputaran kas yaitu 17,43 yang artinya perputaran kas selama satu periode mengalami 17 kali. Kemudian pada tahun 2011 perputaran kas mengalami penurunan menjadi 15 kali putaran yang menunjukkan bahwa perusahaan kurang baik dalam menginvestasikan kasnya. Pada tahun 2012 rata rata perputaran kas mengalami peningkatan menjadi 17 kali putaran. Pada tahun 2013 perusahaan menunjukkan rata rata perputaran kasnya yaitu sebesar 16 kali putaran. Tingkat perputaran kas tertinggi dimiliki oleh PT Tunas Ridean Tbk yang memiliki nilai rata - rata sebesar 32,59 atau 33 kali perputaran kas hal ini terjadi karena jumlah kas relatif kecil dan penjualan dari tahun ke tahun mengalami kenaikan sedangkan tingkat perputaran terendah dimiliki oleh PT. Multi Prima Sejahtera, Tbk yang rata rata perputaran kasnya sebesar 1,73 atau 2 kali perputaran kas. Hal ini terjadi karena adanya jumlah kas dalam jumlah yang besar sehingga mencerminkan banyaknya dana yang menganggur atau kurang efektifnya dalam pengelolan kas .Perputaran kas yang terjadi di perusahaan Otomotif dan Komponennya periode tahun 2010 - 2013 dengan rata rata perputaran kas mengalami 16,35 kali atau 16 kali perputaran kas termasuk dalam kriteria cukup baik.

Perputaran

Persediaan digunakan untuk hubungan antara volume penjualan dengan jumlah persediaan yang dimiliki selama periode berjalan. Tingkat perputaran persediaan yang tinggi mengidentifikasikan bahwa tingkat penjualan yang tinggi. Jumlah perputaran persediaan perusahaan otomotif dan komponennya menunjukkan penurunan dari awal hingga akhir periode. Pada tahun 2010 yang merupakan awal periode menunjukkan tingkat rata - rata perputaran persediaan tertinggi yaitu 7,06 atau 7 kali putaran. Kemudian pada tahun 2011 perputaran persediaan mengalami penurunan menjadi 6,84. Pada tahun 2012 perputaran persediaan kembali mengalami penurunan menjadi 6,10. Kemudian pada tahun 2013 perputaran persediaan juga mengalami penurunan menjadi 5,69. Hal ini dapat disimpulkan bahwa perusahaan otomotif dan komponennya mengalami penurunan perputaran persediaan yang mengakibatkan menurunnya penjualan.

Tabel 4. Perputaran Persediaan Perusahaan Otomotif dan Komponennya 


\begin{tabular}{|c|c|c|c|c|c|c|}
\hline \multicolumn{7}{|c|}{ Rerputaran Persediaan } \\
\hline \multirow{2}{*}{ Kode. } & \multicolumn{4}{|c|}{ Tahun } & \multirow{2}{*}{$\begin{array}{l}\text { Rata - rata } \\
\text { Perusahaan }\end{array}$} & \multirow{2}{*}{ Kriteria } \\
\hline & 2010 & 2011 & 2012 & 2013 & & \\
\hline ASII & 11,38 & 11,43 & 11,13 & 10,67 & 11,15 & Tinggi \\
\hline GJTL & 8,11 & 7,4 & 6,46 & 6,11 & 7,02 & Cukug \\
\hline IMAS & 8,35 & 7,03 & 5,51 & 4,2 & 6,27 & Cuksug \\
\hline LPIN & 1,33 & 1,35 & 1,61 & 1,37 & 1,41 & Rendah. \\
\hline PRAS & 2,48 & 2,77 & 2,3 & 1,89 & 2,36 & Rendah. \\
\hline SMSM & 3,33 & 4,09 & 3,92 & 4,22 & 3,88 & Rendah. \\
\hline TURI & 15,91 & 14,3 & 11,52 & 10,82 & 13,14 & Tinggi \\
\hline UNTR & 5,6 & 6,38 & 6,35 & 6,22 & 6,14 & Cukus \\
\hline $\begin{array}{l}\text { Rata - rata } \\
\text { pectahun }\end{array}$ & 7,06 & 6,84 & 6,1 & 5,69 & 6,42 & Cukug \\
\hline Max & 15,91 & 14,3 & 11,52 & 10,82 & 13,14 & Tinggi \\
\hline Min & 1,33 & 1,35 & 1,61 & 1,37 & 1,42 & Rendah. \\
\hline
\end{tabular}

Berdasarkan perhitungan uji $\mathrm{t}$ menunjukkan bahwa nilai signifikansi pada variabel laba $\left(\mathrm{X}_{1}\right)$ sebesar 0,329 sedangkan alpha $(\alpha)$ sebesar 0,05 karena signifikansi t lebih besar dari $\alpha$ atau 0,329 $>$ 0,05 maka hipotesis nol diterima dan hipotesis alternatif ditolak. Berdasarkan hasil tersebut dapat disimpulkan bahwa tidak ada pengaruh yang signifikan variabel laba terhadap kondisi financial distress.

Berdasarkan hasil perhitungan dan uraian tersebut, dapat dikatakan bahwa perusahaan yang tidak mengalami laba, tidak dapat dipastikan bahwa perusahaan mengalami kondisi keuangan yang buruk atau financial distress. Sedangkan, jika perusahaan yang mengalami laba, hal tersebut juga belum tentu menggambarkan bahwa perusahaan tidak mengalami masalah keuangan atau financial distress. Kemungkinan besar perusahaan yang mengalami masalah keuangan atau financial distress disebabkan oleh faktor internal perusahaan itu sendiri. Dengan demikian, berdasarkan hasil penelitian ini diperoleh bahwa laba bukan satu-satunya tolak ukur untuk mengetahui perusahaan yang mengalami masalah keuangan atau financial distress.

\section{KESIMPULAN}

Berdasarkan hasil penelitian dan hipotesis yang telah dilakukan dan melalui beberapa tahap tentang pengaruh perputaran kas dan perputaran persediaan terhadap profitabilitas pada perusahaan otomotif dan komponennya yang terdaftar di Bursa Efek Indonesia (BEI) periode 2010-2013, maka peneliti dapat menarik kesimpulan sebagai berikut: (1) Perputaran Kas yang terjadi di perusahaan Otomotif dan Komponennya periode Tahun 2010 2013 rata rata mempunyai perputaran kas sebanyak 16 kali putaran dan termasuk dalam kriteria cukup. (2) Perputaran Persediaan yang terjadi di perusahaan Otomotif dan Komponennya periode Tahun 2010 - 2013 rata rata mempunyai perputaran Persediaan sebanyak 6 kali putaran dan termasuk dalam kriteria cukup. (3) Profitabilitas yang terjadi di perusahaan Otomotif dan Komponennya periode Tahun 2010 2013 rata rata mempunyai Profitabilitas sebesar $10,12 \%$ dan termasuk ke dalam kriteria cukup. (4) Hasil pengujian korelasi perputaran kas menunjukan perputaran kas sangat rendah dan mempunyai arah negatif, Sedangkan perputaran persediaan menunjukan korelasi yang rendah. Hasil pengujian perputaran kas dan perputaran persediaan terhadap profitabilitas menyatakan bahwa perputaran kas dan perputaran persediaan secara simultan tidak berpengaruh terhadap profitabilitas pada perusahaan otomotif dan komponennya yang terdaftar di Bursa Efek Indonesia (BEI) periode 20102013. Begitu juga secara parsial masing - masing variabel tidak berpengaruh terhadap profitabilitas. Dari hasil uji 
koefisien determinasi menunjukan hanya 8,7 \% pengaruh perputaran kas dan perputaran persediaan terhadap profitabilitas sedangkan 91,3 \% dipengaruhi oleh faktor faktor lain yang tidak dimasukan dalam penelitian ini.

\section{DAFTAR PUSTAKA}

1. Handayani R. Sri, Siskawati Nelva. (2016). Pengaruh Perputaran Kas Terhadap Gross Profit Margin Pada Perusahaan Farmasi Yang Terdaftar di Bursa Efek Indonesia. ISSN : 2443-2466 Volume 2 No. 2, Halaman 1-11.

2. Hariyanto Mamang. (2018). Pengaruh Laba dan Arus Kas Terhadap Kondisi Financial Distress. Aktiva Jurnal Akuntansi dan Investasi, Volume 3 No.1, Halaman 44-60.

3. Michelia Putri Catherina Sujatna, Yulia Hayatul, Syauqy Syauqy Abdul Muluk (2018) Pengaruh Laba Dan Perputaran Kas Terhadap Kondisi Financial Distress Perusahaan

4. Ramadhani Nurlia. (2017). Analisis Laporan Arus Kas Untuk Menilai Kinerja Keuangan Pada PT Handjaya Mandala Sampoerna, Tbk. Yang Terdaftar di Bursa Efek Indonesia. Jurnal Financial, Volume 3 No.1, Halaman 19-26.

5. Subani. (2015). Analisis Arus Kas Untuk Mengukur Kinerja Keuangan (Studi Pada KUD Sido Makmur Lumajang). Subani, Volume 5 No.1, Halaman 58-67.

6. Surya Sarjito, Ruliana Ruly, Soetama Dedi Rossidi. (2017). Pengaruh Perputaran Kas dan Perputaran Persediaan Terhadap Profitabilitas. Akuntabilitas: Jurnal
Ilmu Akuntansi, Volume 10 (2), Halaman 313-332. 